WALDEMAR W. ŻUREK* - LUBLIN

\title{
SALEZJANIN Z ,TRAMWAJU”. KOADIUTOR STANISŁAW ŻUKOWSKI 1913-2009
}

Dnia 23 IV 2009 roku zmarł w salezjańskim Zakładzie im. Ks. Bosko w Oświęcimiu brat zakonny - u salezjanów nazywany koadiutorem - Stanisław Żukowski, który w długim okresie czasu pełnił funkcję portiera zakładowego. Przez wiele lat, do początku lat 90. ubiegłego stulecia, mieszkał w bardzo skromnych warunkach. Jego maleńki pokój mieścił się w wydzielonej części korytarza wejściowego do zakładu. Powierzchnia tego pokoju wynosiła ok. 9 metrów kwadratowych, stąd mówiono na co dzień, że Stanisław mieszka w tramwaju.

W mowie zdradzał swój wschodni, wileński akcent. Gdy do zakładu wracał wychowanek po zamknięciu drzwi zakładowych o godz. 22.00, a portier, pan Stanisław, usłyszał dzwonek, podchodził do drzwi i rutynowo pytał: kto tam? Gdy słyszał odpowiedź: wychowanek - pan Stanisław mówił: legitymację proszę. Oczekujący podawał swoją legitymację przez dość dużą dziurę ,judasza"; po sprawdzeniu tożsamości następowało wpuszczenie proszącego do zakładu. Nie tylko wychowankowie ale i współbracia salezjanie żartobliwie odgrywali scenę wpuszczania do zakładu chłopców przez pana Stanisława. Najbardziej bawiło odtwarzanie nie tyle procedury wejścia ile melodyjny akcent wileński w mowie zdradzający jego pochodzenie.

Przekazywany tutaj obraz życia pana Stanisława opiera się w dużej mierze na jego osobistej relacji i świadomości, jaką w sobie ukształtował i przechowywał, a zatem nacechowany jest subiektywną wizją wydarzeń oraz interpretacją ich sensu. Łączy się z tym również sposób zapisu i przekazu tych relacji, prowadzone z myślą o możliwie wiernym zachowaniu cech osobowości i stylu przekazu bohatera naszego sprawozdania.

* Waldemar W. Żurek SDB - dr hab. historii Kościoła, dyrektor Ośrodka Archiwów Bibliotek i Muzeów Kościelnych KUL, Wydział Teologii KUL. 


\section{W wielodzietnej rodzinie}

Stanisław urodził się dnia 19 I 1913 roku w miejscowości Zadworańce ${ }^{1}$, powiat Wileńsko-Trocki, parafia Kalwaria koło Wilna, zwana później Wileńską ${ }^{2}$. Dnia następnego przyjął sakrament chrztu świętego w rodzinnej parafii. Był synem Piotra (ur. ok. 1880, s. Jana) i Zofii z domu Lipniewicz (ur. ok. 1880). Pochodził z wielodzietnej rodziny. Jego rodzeństwo stanowili wyłącznie bracia: Antoni (ur. ok. 1899) - zmarł po paru miesiącach, Witold (ur. w 1900), Franciszek (ur. w 1903), Piotr - zmarł około 10 roku życia, Władysław (ur. w 1910, zm. w 1950), Jan (ur. w 1916). Najmłodszy z braci Stanisława - Jan był bardzo zdolnym uczniem. Otrzymał stypendium w Seminarium Nauczycielskim koło Ostrej Bramy w Wilnie. Zmarł w 18 roku życia, jako uczeń czwartej klasy³.

Do wiejskiej szkoły podstawowej uczęszczał Stanisław od 1923 roku w Zabłociu i Bojarach, a od czwartej klasy uczył się w Kalwarii, zwanej także Jerozolimką. Siedmioklasową Publiczną Szkołę Powszechną im. Stanisława Jachowicza nr 50 w Wilnie ukończył w 1929 roku. Na świadectwie otrzymał wówczas oceny: bardzo dobry - ze sprawowania i nauki religii; dobry - z języka polskiego, rachunków z geometrią, geografii i nauki o Polsce współczesnej, historii, rysunków, robót ręcznych, śpiewu, ćwiczeń cielesnych; dostateczny - z języka niemieckiego i przyrody (z przyrody żywej, fizyki i chemii oraz higieny). Wynik ogólny na świadectwie otrzymał dobry ${ }^{4}$.

W 1923 roku w parafii rodzinnej przystąpił Stanisław do pierwszej spowiedzi, a w roku następnym do Komunii świętej. Sakramentu bierzmowania udzielił

\footnotetext{
${ }^{1}$ Nazwa Zadworańce (Zadworzańce) oznacza położenie wioski za dworem w Bukiszkach koło Wilna. Wieś w powiecie wileńskim, gmina Rzesza, okręg wiejski i dobra (Radziwiłowiczów) Bukiszki, o 10 wiorst od Wilna. W budynku dworu mieściła się powiatowa szkoła rolnicza, późniejsza szkoła traktorzystów. Slownik geograficzny Królestwa Polskiego i innych krajów słowiańskich, red. B. Chlebowski, J. Krzywicki, F. Sulimierski W. Walewski, t. 14, Warszawa 1895, s. 252.

${ }^{2}$ W latach 1755-1772 dominikanie wileńscy wybudowali w Kalwarii klasztor i kościół oraz stacje Drogi Krzyżowej z 35 kapliczkami rozsianymi po lesie kalwaryjskim. Po kasacie klasztoru przez cara w 1850 r. kościół klasztorny został świątynią parafialną. W 1932 r. do parafii należało 4.350 wiernych z następujących miejscowości: miasto Kalwaria (Wilno). Wioski i osady: Awiżenie, Babińce, Bałeli, Bojary, Bołtupie, Bukiszki-kolonia, Dubliszki, Dworzyszcze, Fabjaniszki, Felicjanowo, Góra Szaszkinia, Gulbiny-osada, Małe-Gulbiny, Wielkie-Gulbiny, Jerozolimka, Kremple, Krzyżaki, Nowosiółki, Nowo-Werki, Oszkińce, Podwileńce, Praszyszki, Rzesza-Werkowska, Skiersinie, Stawiszki, Taranda I i II, Trynopol, Wanaginie, Wyszary, Zabłocie, Zadworańce, Zgoda. Zaścianki: Bałsia, Kryniczki, Krzyżaki, Marjan-Dolina, Ponaryszki, Raj. Folwarki: Grzymajłówka, Klonówka, Krzyżaki, Rojstaniszki, Warnolepka, Werlinka, Żurowice. Majątek Werki. Synodus Archidioecesana Vilnensis, Vilno 1932, s. 475; Wilno pielgrzymkowe. Przewodnik śladami świętych i błogosławionych, opr. Cz. Paczkowska, Wilno 2002, s. 168-171.

${ }^{3}$ Archiwum Salezjańskiej Inspektorii Krakowskiej (dalej: ASIK), b. sygn., Zespół: zmarli współbracia. Teczka personalna koad. Żukowskiego Stanisława, Świadectwo metryczne urodzenia i chrztu Stanisława Żukowskiego wydane w Kalwarii 19 IV 1938 r. nr 501 (nr aktu 9); Relacja koad. Stanisława Żukowskiego z dnia 7 II 2003 r. w Oświęcimiu (zbiory autora).

${ }^{4}$ ASIK, b. sygn., Zespół: zmarli współbracia. Teczka personalna koad. Żukowskiego Stanisława, Świadectwo (nr 5) ukończenia szkoły Stanisława Żukowskiego w Wilnie w roku szkolnym 1928/1929 wydane 20 VI 1929 r. w Wilnie.
} 
mu dnia 24 V 1926 roku w Kalwarii Wileńskiej metropolita wileński arcybiskup Romuald Jałbrzykowski. Po ukończeniu szkoły podstawowej natychmiast Stanisław wstąpił do Stowarzyszenia Młodzieży Polskiej. Co roku w patronalne święto świętego Stanisława Kostki (13 listopada) ze sztandarami druhowie i druhny stowarzyszonej młodzieży szli do kościoła na Mszę świętą i przystępowali do sakramentów świętych. Podobnie było na święto niepodległości Polski dnia 11 listopada, obchodzone uroczyście w najbliższą po tej dacie niedzielę oraz na liturgiczne święto Niepokalanej -8 grudnia. Pracę w tej organizacji katolickiej rozpoczął jako sekretarz. Już wówczas od swojej młodości Stanisław pracował nad szerzeniem oświaty i życia religijnego wśród młodzieży. To zaangażowanie kontynuował w późniejszych latach w tej organizacji przemianowanej na Katolickie Stowarzyszenie Młodzieży Męskiej, pełniąc funkcję bibliotekarza. Pracę i zaangażowanie w tej organizacji katolickiej na rzecz rówieśników z perspektywy czasu ocenił Stanisław jako najszczęśliwsze lata młodości ${ }^{5}$.

Ogromnie zasłużonym działaczem oświatowym i społecznym na terenie Wilna okazał się w latach 1908-1942 ks. Stanisław Miłkowski' ${ }^{6}$, początkowo jako

${ }^{5}$ Katolickie inicjatywy organizacyjne obejmujące młodzież męską i żeńską po 1918 r. rozwijały się w skali krajowej w ramach stowarzyszeń, organizacji i ruchów. Działalność Stowarzyszeń Młodzieży Polskiej w okresie międzywojennym koordynowana była w diecezjach polskich przez Związki Stowarzyszeń Młodzieży Polskiej Męskiej i Żeńskiej. Po utworzeniu w 1930 r. Akcji Katolickiej związane zostały z nią istniejące organizacje katolickie. W celu ujednolicenia struktury Akcji Katolickiej Konferencja Episkopatu Polski podjęła dnia 19 VI 1934 r. decyzję o unifikacji organizacji i stowarzyszeń wchodzących w jej skład. Obok Katolickiego Stowarzyszenia Mężów i Katolickiego Stowarzyszenia Kobiet powołane zostało wówczas Katolickie Stowarzyszenie Młodzieży Męskiej (KSMM) oraz Katolickie Stowarzyszenie Młodzieży Żeńskiej (KSMŻ) działające dotychczas jako Stowarzyszenie Młodzieży Polskiej na terenie diecezji. T. Biedroń, Katolickie Stowarzyszenia Młodzieży, EK, t. 8, k. 1112-1113; S. Skwierczyński, Katolickie Stowarzyszenia, EK, t. 8, k. 1093; ASIK, b. sygn., Zespół: zmarli współbracia. Teczka personalna koad. Żukowskiego Stanisława, Życiorys Stanisława Żukowskiego napisany w Kopcu dnia 8 V 1960 r., Proboszcz parafii Kamionka (dekanat Turgiele) do przełożonego salezjanów w Kopcu k. Częstochowy - zaświadczenie o przyjęciu sakramentu bierzmowania przez Stanisława Żukowskiego z dnia 12 IX 1960 r.- Kamionka (nr 19), Koad. St. Żukowski do inspektora ks. Marka Chrzana z 24 IX 2008 r.- Oświęcim.

${ }^{6}$ Ks. Miłkowski (1881-1906-1961), kapłan arch. wileńskiej. Szkołę średnią ukończył w Grodnie, studiował w seminarium duchownym w Wilnie i Akademii Duchownej w Petersburgu, gdzie uzyskał magisterium z teologii. Skierowany na studia do Fryburga Szwajcarskiego, zmuszony był powrócić po pół roku z braku stypendium na pokrycie kosztów studiów. Podjął pracę jako wikariusz parafii Wszystkich Świętych (1908-11), profesor seminarium duchownego (1914-26) i prokurator. Tam dał się poznać jako aktywny działacz oświatowy i społeczny. Od maja $1940 \mathrm{r}$. był proboszczem parafii Nowa Wilejka i w czasie okupacji pomagał Żydom. W marcu 1942 r. aresztowany przez Niemców i więziony przez miesiąc na Łukiszkach w Wilnie. W latach 1946-1949 ponownie był proboszczem w Kalwarii pod Wilnem. Po zabraniu sprawki, do 1951 r. nie mógł spełniać funkcji duszpasterskich. Mieszkał w Trokach i w Nowej Wilejce. Dzięki staraniom wiernych parafii Derewna (diec. pińska, koło Iwieńca, powiat Baranowicze, Białoruśka SSR) w Radzie Najwyższej ds. Religii w Moskwie, otrzymał dnia 17 XI 1951 r. ks. Miłkowski pozwolenie na pracę w tej parafii. Tam był dwukrotnie pozbawiony sprawki. Schorowanemu i podeszłemu w latach kapłanowi odmówiono ostatecznie w listopadzie 1958 r. możliwości wyjazdu do Polski. Zmarł w Derewnej 15 V 1961 r. i został pochowany na cmentarzu parafialnym. Miłkowski Stanisław, w: R. Dzwonkowski, 
duszpasterz młodzieży akademickiej, od 1919 roku moderator Sodalicji Mariańskiej. Pod jego bezpośrednim wpływem wzrastał Stanisław gdy ks. Miłkowski pełnił dwukrotnie obowiązki proboszcza w Kalwarii w latach 1932-1934 oraz 1946-1949. W czasie pracy w Kalwarii był ks. Miłkowski równocześnie dyrektorem domu rekolekcyjnego.

W okresie międzywojennym pielgrzymowanie do Kalwarii (Wileńskiej) przeżywało prawdziwy rozkwit. Pielgrzymowanie dróżkami Męki Pana Jezusa w Kalwarii (zwanej także Jerozolimką), podobnie jak nawiedzenie Ostrej Bramy w Wilnie, uważane było na tych terenach za odpust całego życia. Rozważanie męki Zbawiciela w czasie Drogi Krzyżowej należało do najbardziej rozpowszechnionych form pobożności. W tym czasie przybył do Kalwarii na proboszcza w 1932 roku ks. Stanisław Miłkowski. Pracował wprawdzie tylko dwa lata ale okazał się energicznym duszpasterzem. Wprost tragiczny okres dla tej miejscowości pielgrzymkowej rozpoczął się w 1941 roku, gdy władze komunistyczne zabroniły odprawiania Drogi Krzyżowej a ruch pielgrzymkowy, głównie z dalszych okolic, z każdym rokiem malał. Pewnej nocy 1962 roku na rozkaz władz sowieckich żołnierze Armii Czerwonej wysadzili w powietrze wszystkie bramy Jerozolimskie i większość kaplic Drogi Krzyżowej. Ocalały jedynie cztery?

Od dzieciństwa Stanisław pracował z braćmi na gospodarstwie rodzinnym, którego areał wynosił 9 hektarów. Na skutek komasacji gospodarstw przeprowadzonej tuż przed II wojną światową przy rodzicach pozostało 4 hektary. Od młodości był rozmiłowany w książkach, więc dużo czytał. Pod wpływem lektury Trylogii Henryka Sienkiewicza wyobrażał sobie i marzył ileż to czynów bohaterskich można dokonać dla ojczyzny, stąd zastanawiał się, czy nie zostać na służbę w wojsku nadterminowo, jako żołnierz zawodowy. Dlatego do wojska poszedł w 1935 roku z radością. W czasie służby wojskowej przenosił rozmaite dokumenty i miał okazję wiele widzieć, dowiedzieć się i doczytać. W tym czasie dowiedział się ile wojska ma wówczas Rosja i Niemcy, do żołnierzy dochodziły również informacje o zbrojeniach, łatwo było przewidzieć, że zbliża się wojna ${ }^{8}$.

W wojsku Stanisław służył niecałe dwa lata (od września 1935 do września 1937) w 23. Pułku Ułanów Grodzieńskich ${ }^{9}$ stacjonującym w Postawach koło Łyn-

Leksykon duchowieństwa polskiego represjonowanego w ZSRR 1939-1988, Lublin 2003, s. 422424; W. Wężyk-Widawska, Ksiądz Stanisław Miłkowski (1881-1962), w: Chrześcijanie, t. 7, red. B. Bejze, Warszawa 1982, s. 9-113.

${ }^{7}$ Dekretem papieża Piusa XI z 1931 r. odpust zupełny mógł uzyskać każdy, kto odprawił Drogę Krzyżową, przystąpił do Sakramentu Pokuty, uczestniczył w Eucharystii i przyjął komunię świętą. Wilno pielgrzymkowe, s. 172-173.

${ }^{8}$ ASIK, b. sygn., Zespół: zmarli współbracia. Teczka personalna koad. Żukowskiego Stanisława, Koad. St. Żukowski do inspektora ks. Marka Chrzana z 24 IX 2008 r. - Oświęcim; Relacja koad. S. Żukowskiego z dnia 7 II 2003 r. w Oświęcimiu (zb. aut.).

923 Pułk Ułanów - oddział kawalerii Wojska Litwy Środkowej i Wojska Polskiego II Rzeczypospolitej. Numer „23” pułk otrzymał 1 VI 1921 r. Dokładnie rok później nadano mu sztandar. Oddział sformowany w 1920 r. w wyniku utworzenia 3 Dywizjonu Strzelców Konnych, 211 Pułku Ułanów i 2 Dywizjonu Huzarów Litwy Środkowej. Na czapkach rogatywkach mieli otok pomarańczowy. Proporczyk pomarańczowo-biały z wąskim paskiem biało pomarańczowym pośrodku. Pułk prowadził działania zbrojne w wojnie polsko-bolszewickiej i kampanii wrześniowej. Na skutek strat 
tup, w północno-wschodniej Polsce w pobliżu granicy sowieckiej. W czasie służby wojskowej przeszedł 6-miesięczne szkolenie w szkole podoficerskiej w Grodnie uzyskując stopień kaprala wojsk łączności. Wówczas doskonale nauczył się nawigacji, $\mathrm{w}$ tym poruszania się $\mathrm{w}$ terenie na podstawie obserwacji gwiazd nocą. Po ukończonej służbie wojskowej w 1937 roku Stanisław czym prędzej wracał do domu rodzinnego. Były to lata niespokojne i miały miejsce zamieszki zwrócone przeciw Żydom. Jego ojciec z bratem (Stanisława), który był zelatorem Akcji Katolickiej, poszli pewnego dnia to szynku. Podpiwszy nieco, powiedzieli do właściciela szynku, Żyda: dawaj wódki, bo ci to rozwalimy. Żona właściciela usłyszała te słowa i poszła z donosem na policję. Została założona sprawa. Wyrok dla obu brzmiał: miesiąc aresztu, ale bez zapisu do akt, że byli karani, albo do więzienia i z wpisem o karalności nałożonej przez sąd. Obaj siedzieli w więzieniu, więc Stanisław musiał czym prędzej wracać z wojska do domu rodzinnego, gdzie czekało go mnóstwo pracy na gospodarstwie. Nawet zrezygnował z końcowej defilady i z książeczką wojskową wrócił do domu ${ }^{10}$.

Odbyta służba wojskowa, lektura osobista oraz obserwacja życia i wypadków wskazywała według Stanisława, że Niemcy i Rosja bolszewicka przygotowują się do wojny. A jeśli wybuchnie wojna, to on na pewno zostanie zmobilizowany i zginie, więc należy się przygotować na śmierć. Tak sądził Stanisław. Od młodości odczuwał pragnienie powołania do służby Bożej w zakonie, a religijna atmosfera domu rodzinnego sprzyjała stopniowej krystalizacji wewnętrznego głosu do tego rodzaju życia. Dowiedział się, że za Warszawą w Niepokalanowie ojciec Maksymilian Kolbe założył klasztor franciszkanów i nawołuje młodzieńców do wstąpienia do klasztoru aby przez pracę w wydawnictwie Rycerza Niepokalanej szerzyć chwałę Bożą i Niepokalanej. Zdecydował się napisać do Niepokalanowa. Gdy otrzymał odpowiedź pozytywną, wyjechał i dnia 14 IX 1938 roku został przyjęty do Zakonu Ojców Franciszkanów w Niepokalanowie jako kandydat na brata zakonnego ${ }^{11}$.

W klasztorze bracia zakonni mówili o ojcu Kolbe, że to człowiek święty. Stanisław tłumaczył sobie, że święci są w niebie a na ziemi ludzie dążą do świętości. Stanisław obserwował życie, pracę i modlitwę zakonników, słuchał konferencji

w walkach z Niemcami i rozproszenia pułk został rozformowany w połowie października $1939 \mathrm{r}$. B. Królikowski, Czas ułanów. Polski wrzesień 1939, Warszawa 1993, s. 168-173; K. Satora, Opowieści wrześniowych sztandarów, Warszawa 1990, s. 238-240.

${ }^{10}$ ASIK, b. sygn., Zespół: zmarli współbracia. Teczka personalna koad. Żukowskiego Stanisława, Życiorys Stanisława Żukowskiego napisany w Kopcu dnia 8 V 1960 r., Koad. Żukowski do inspektora ks. Chrzana z 24 IX 2008 r. - Oświęcim.

${ }^{11}$ Droga powołania franciszkańskiego dla Stanisława była poddana wielu próbom. Pod wpływem lektury Rycerza Niepokalanej pomyślał o franciszkanach. Zgłosił się do ojca gwardiana franciszkanów w Grodnie przy ul. Trockiej, ale powiedziano mu, że tu kandydatów do zakonu nie przyjmują. Napisał więc list do Niepokalanowa z prośbą o przyjęcie, skąd otrzymał odpowiedź odmowną. Po wojsku w 1937 r. napisał ponownie list o przyjęcie do franciszkanów. Odpowiedź z klasztoru ktoś (z rodziny?) przejął i nie oddał mu. Więc napisał po raz kolejny i dopiero tym razem otrzymał odpowiedź pozytywną. ASIK, b. sygn., Zespół: zmarli współbracia. Teczka personalna koad. Żukowskiego Stanisława, St. Żukowski do Księży Salezjanów z 18 IX 1958 r.- Zadworańce, Koad. Żukowski do inspektora ks. Chrzana z 24 IX 2008 r. - Oświęcim. 
gwardiana klasztoru o. Kolbe i postanowił sobie, że musi być jeszcze świętszy niż o. Kolbe, w myśl słów Pisma Swiętego: „Bądźcie wy doskonali jak Ojciec wasz niebieski”. A to było ponad jego możliwości i wzór niedosięgły. Po kilkumiesięcznej aspiranturze dnia 2 V 1939 roku otrzymał habit zakonny, koronkę oraz pasek św. Franciszka z rąk ówczesnego gwardiana, dziś świętego o. Maksymiliana Marii Kolbe. Przyjął wówczas imię zakonne brat Leokadiusz. Od tego czasu rozpoczął postulantat zakonny (do 5 IX 1939) pracując w niepokalanowskim klasztorze przy maszynach drukarskich, w zecerni i drukarni. Tymczasem zbliżała się wojna ${ }^{12}$.

\section{Druga wojna światowa}

Wybuch drugiej wojny światowej zastał brata Stanisława w Niepokalanowie. Już w połowie lipca 1939 roku otrzymał wezwanie mobilizacyjne do stawienia się w 1. Pułku Szwoleżerów w Warszawie. Wezwanie przyjął spokojnie. Jeżeli taka jest wola Boża, aby zmienić habit franciszkański na mundur wojskowy, to był gotowy. Wczytując się w wezwanie mobilizacyjne zauważył Stanisław błąd. W rubryce imion rodziców było napisane, iż jest synem Joachima i Anny, w rzeczywistości był synem Piotra i Zofii. Brat zakonny zajmujący się sprawami meldunkowymi w klasztorze niepokalanowskim zaniósł jego wezwanie do biura mobilizacyjnego. Tam urzędnik przyjął je z powrotem i oznajmił, że Żukowski ma pozostać w Niepokalanowie do pracy w drukarni. Wstępując do klasztoru w Niepokalanowie Stanisław ofiarował Niepokalanej swoje życie. A Niepokalana na karcie mobilizacyjnej umieściła imiona swoich Rodziców: Joachima i Anny, zamiast imion jego rodziców i dzięki temu „błędowi” nie poszedł na wojnę. Tak tłumaczył Stanisław u schyłku swego życie tamto zdarzenie, w które wierzył szczerze ${ }^{13}$.

Niestety już 5 IX 1939 roku musiał uciekać w powszechnym exodusie przed przeważającą siłą wroga. Po 1 września tego roku nadszedł do Niepokalanowa rozkaz władz wojskowych (PKU), aby wszyscy mężczyźni w wieku poborowym przeszli na wschód od Wisły. W tej sytuacji ojciec Kolbe radził aby bracia zakonni, którzy mają rodziny na wschodzie, powrócili do domów rodzinnych, dawali dobre świadectwo swojej wiary i życia zakonnego, a po wojnie wszyscy będą przyjęci do klasztoru w Niepokalanowie. Wraz z innymi braćmi Stanisław opuścił 5 IX 1939 roku Niepokalanów. Podczas wędrówki ze względu na grożące osobom zakonnym niebezpieczeństwo ubrał cywilne ubranie. To jednak nie uchroniło go od aresztowania. Niemcy przedarli się na linii kolejowej, więc Stanisław wsiadł do pociągu do Lublina. Pociąg zatrzymał się w Mińsku Mazowieckim. Tam stali dłużej, więc na własną rękę zdecydował się uciekać dalej, kierując się na północny wschód - na Wilno. Szedł głównie nocą, według położenia gwiazdy północy. Tę

${ }^{12}$ ASIK, b. sygn., Zespół: zmarli współbracia. Teczka personalna koad. Żukowskiego Stanisława, Życiorys Stanisława Żukowskiego napisany w Kopcu dnia 8 V 1960 r.

${ }^{13}$ ASIK, b. sygn., Zespół: zmarli współbracia. Teczka personalna koad. Żukowskiego Stanisława, Koad. Żukowski do inspektora ks. Chrzana z 24 IX 2008 r.- Oświęcim. 
umiejętność poznał dobrze w wojsku. Tak dotarł na własną rękę pieszo do Puszczy Białowieskiej. Trzeba było przejść przez miasteczko Hajnówkę. W tym czasie żołnierze Wojska Polskiego walczący o miasto Płock pod wodzą gen. Władysława Andersa, po przegranej bitwie wycofując się na wschód, znaleźli się w miejscowości Hajnówka, gdzie dopadli ich Niemcy. Rozpoczęła się walka. Polacy rozbili kilka działek, zniszczyli dwa czołgi nieprzyjaciela, zabili kilku Niemców i wycofali się do Puszczy Białowieskiej. Tymczasem Niemcy postanowili zemścić się na ludności cywilnej. W Hajnówce wzdłuż ulicy na chodnikach ustawili uzbrojonych żołnierzy, a każdy z cywilów wchodzących do miasta mógł dojść tylko do rynku, dalej droga była zamknięta. Gdy zatrzymali około 100 mężczyzn w wieku poborowym, w tym i Stanisława, ustawili ich dwójkami i poprowadzili przez pole w pobliże zabitego żołnierza niemieckiego, a następnie przywiedli pojmanych przed rozbite czołgi niemieckie. Tu ustawili ich wzdłuż rowu przydrożnego i kazali czekać. Tak ustawieni stali 3 godziny. Ludzie obserwujący tę scenę nawet nie płakali na ich widok. Ucieczka była niemożliwa gdyż pilnowali ich uzbrojeni żołnierze niemieccy. Po kilku godzinach oczekiwania nadjechał na motocyklu w czarnym płaszczu oficer niemiecki i oznajmił radosną dla Niemców nowinę, że Armia Czerwona przekroczyła granicę Polski i wojna się skończyła, więc żołnierze wrócą do domów i zacznie się odbudowa kraju. Po takiej wiadomości Polakom nie chciało się żyć: nie ma już Polski - ojczyzny najdroższej. Słuchając tych słów Stanisław stał nad rowem, w pobliżu rosłego krzewu, na który nikt nie zwracał uwagi. Oficer niemiecki zakończył przemówienie słowami: „z powodu tej radości darujemy wam życie, możecie wracać do domów". Wówczas poruszyły się zarośla, opadły na ziemię krzewy i ukazał się żołnierz niemiecki z ciężkim karabinem maszynowym z długą taśmą amunicji przeznaczonej dla stojących nad rowem do rozstrzelania. Wówczas Stanisław uświadomił sobie jakie groziło mu niebezpieczeństwo, bowiem stał w odległości ok. 30 metrów od karabinu. A może lepiej zginać od razu? - myślał. Niemcy doszli tak daleko, a tu ze wschodu kolejny agresor sowiecki napadł na Polskę. Działo się to 18 IX 1939 roku. Dzisiaj w tym dniu obchodzi się liturgiczne wspomnienie patrona młodzieży, św. Stanisława Kostki, a Stanisław co roku powracał w dniu swoich imienin do tego smutnego wydarzenia ${ }^{14}$.

Po odzyskaniu wolności Stanisław udał się w dalszą drogę na wschód. W Grodnie toczyły się walki z agresorem radzieckim. Wojsko polskie opuściło miasto pozostawiając karabiny. Wówczas tamtejsi studenci pobiegli na rynek po karabiny, uzbroili się i stanowczo zapewniali, że nie oddadzą Grodna. Walczący studenci przeciągnęli przez most drut kolczasty, a tego naprawdę przestraszyli się sowieci. Zniszczyli sowietom kilka czołgów i rozpoczęła się walka o miasto. W tym czasie przybył do Grodna Stanisław. Zobaczył tu olbrzymią ilość czołgów, przechodził między nimi. Po dłuższym czasie zatrzymali go sowieci. Zaprowadzili go do komandira i przedstawili jako szpiega, który przybył liczyć czołgi sowieckie. Tu przesiedział kilka godzin. Dokonali szczegółowej kontroli jego

${ }^{14}$ ASIK, b. sygn., Zespół: zmarli współbracia. Teczka personalna koad. Żukowskiego Stanisława, Koad. Żukowski do inspektora ks. Chrzana z 24 IX 2008 r.- Oświęcim; Relacja koad. St. Żukowskiego z dnia 7 II 2003 r. w Oświęcimiu (zb. aut.). 
„majątku” - tobołka. Podczas tych czynności zabierali wszystko co przedstawiało jakąkolwiek wartość. Następnie zaprowadzili aresztowanego na przedmieścia Grodna i zamknęli w szopie, gdzie przesiedział 3 dni i 2 noce. W grupie zatrzymanych było dwóch księży. Sowieci dawali wówczas aresztowanym jedynie wodę do picia. Nawet do ubikacji udawali się aresztowani pod nadzorem konwoju. Dało się wówczas zauważyć, że niektórzy z zatrzymanych starali się przypodobać sowietom ${ }^{15}$.

Po kilku dniach sowieci zdecydowali Stanisława wypuścić, jako że szedł od Warszawy do Wilna. Przesiedział kilkadziesiąt godzin bez jedzenia i w ogromnym zaduchu. Ogromnie osłabiony zdecydował się pójść do ojców franciszkanów w Grodnie, dzielnica Zaniemeńska ${ }^{16}$. Tamtejszy kościół pw. Najświętszej Maryi Panny Anielskiej zastał Stanisław już zamknięty. Udał się do jadalni zakonnej, gdzie zobaczył psa z rozbitą głową i stłuczoną w pobliżu wazą z zupą. Zdecydował czym prędzej opuścić klasztor, ale ponownie wpadł w ręce sowietów, którzy posądzili go, że ukrywał się w klasztorze. Wytłumaczył im, że już siedział 3 doby. Wówczas puścili go wolnym, a nawet postawili na przedzie kolejki po żywność. Nabrawszy nieco sił, przez puszczę rudnicką przybył dnia 27 IX 1939 roku do Wilna, do ojców franciszkanów na ul. Trocką $6^{17}$. W ten sposób ostatecznie po trzech tygodniach pieszej tułaczki dotarł Stanisław do domu rodzinnego. Tu podjął pracę w rodzinnym gospodarstwie wiejskim, jednocześnie pracując dla chwały Bożej: kwestował na rzecz uwięzionych i potrzebujących pomocy księży i znajo-

${ }^{15}$ Relacja koad. St. Żukowskiego z dnia 7 II 2003 r. w Oświęcimiu (zb. aut.).

${ }^{16}$ Kościół Matki Bożej Anielskiej i klasztor franciszkanów na Zaniemniu (obecnie ul. Gagarina), fundacji starosty upickiego Eustachego Kurcza i żony Zuzanny, zbudowane w 1635 r. Trójnawowa bazylika z pojedynczą wieżą, przebudowana gruntownie w połowie XVIII wieku, była nieprzerwanie czynna. Dwukondygnacyjny korpus klasztorny wzniesiony na planie podkowy wraz z kościołem tworzył zamknięty dziedziniec z wewnętrznym wirydarzem. Obecnie mieści się tu szpital. G. Rąkowski, Ilustrowany przewodnik po zabytkach kultury na Białorusi, Warszawa 1997, s. 64.

${ }^{17}$ Należący do rodów litewskich Gasztołdów - Piotr, nadał teren podmiejski w Wilnie „Na Piasku" na własność franciszkanom, którzy wznieśli tu klasztor i kościół drewniany pw. Wniebowzięcia Najświętszej Marii Panny (zwany zwyczajowo Najświętszej Marii Panny). Murowany, trzynawowy kościół Najświętszej Marii Panny poświęcono w 1421 r. Usytuowany przy głównej drodze zachodniej, należał do najstarszych kościołów Wilna. Pożary w 1533, 1737 i 1748 r. obróciły budowlę w ruinę. Odbudowany w 1774 r. zachował dzisiejszą postać. Klasztor i kościół w 1864 r. zamknięte przez gubernatora wileńskiego Michaiła Murawiewa („Wiszatiela”). Świątynia podzielona na 5 pięter przeznaczona została na archiwum (przez 40 lat). Oddana katolikom przed I wojną światową, przejęta została w latach 30 ubiegłego stulecia przez franciszkanów, którzy odzyskali także dawny klasztor. Odbudowę obiektów franciszkańskich ukończono tuż przed wybuchem II wojny światowej. Po wojnie świątynia Najświętszej Marii Panny została zamknięta przez sowieckie władze i skazana na powolne samozniszczenie. W narożniku dawnego cmentarza grzebalnego (obecnie nieistniejącego) od ul. Trockiej w 1708 r. Michał Suzin wzniósł kaplicę-kostnicę, na pamiątkę wilnian pomordowanych w kościele Najświętszej MP przez moskiewskich Kozaków w 1655 r. W latach Litwy Sowieckiej urządzono w niej sklepik „państwowy” z tzw. „pamiątkami”, m.in. z alkoholem. J. Garniewicz, Światynie wileńskie od czasów najdawniejszych do obecnych. Przewodnik historyczny, Kędzieżyn-Koźle, Wilno, Ryga 1993, s. 91-93; G. Rąkowski, Ilustrowany przewodnik po zabytkach kultury na Litwie, Warszawa 1999, s. 331-332. 
mych, organizował nabożeństwa wieczorne w maju i październiku ku czci Marii Niepokalanej i w czerwcu ku czci Najświętszego Serca Pana Jezusa.

Gdy opuszczał Niepokalanów, on i jemu podobni otrzymali na drogę po 25 złotych. Bank był zamknięty, więc nie mógł rozmienić otrzymanych pieniędzy na drobne. Z Niepokalanowa wyruszył Stanisław z kolegą z Poznania, od którego w czasie drogi otrzymał 50 groszy. W zamian za to oddał mu całe 5 złotych. Podczas tułaczki na wschód prosił o jedzenie, a otrzymawszy, każdorazowo pytał, ile ma zapłacić. Jak wspominał, w czasie tej wędrówki ani razu nie musiał płacić za jedzenie. Decydując się prosić o pożywienie wybierał domy biedniejsze, bo jak sądził „oni dadzą”. Pewnego dnia (w obecnej Polsce) pewną staruszkę mieszkająca samotnie poprosił o jedzenie. Odpowiedziała mu, że ma tylko jedno jajko i dała mu je. Po zjedzeniu miał wyrzuty, że ją tego bardzo skromnego pożywienia pozbawil.

W przededniu wybuchu wojny rozpoczęły się w Kalwarii rekolekcje, które zorganizował ówczesny proboszcz ks. Stanisław Miłkowski. W momencie ogłoszenia mobilizacji zostały one przerwane, a wkrótce tamtejszy dom rekolekcyjny został zajęty przez wojsko, wskutek czego dom zmienił się nie do poznania. Po wejściu wojsk sowieckich i przeżyciu wstrząsu życie wracało do względnie normalnego toku. Dom rekolekcyjny służył jako schronienie dla ludzi bezdomnych z wielu powodów. Jednak ksiądz proboszcz organizował każdego miesiąca w domu rekolekcyjnym dni skupienia ${ }^{18}$.

Po zajęciu naszego kraju sowieci zaczęli nadawać ludziom ziemię. Zabierali gospodarzom, którzy mieli duże areały (np. 70 ha) i dawali innym. Gdy przyszli na te tereny w 1941 roku Niemcy, odbierali przydzieloną gospodarzom przez sowietów ziemię. Gdy Niemcy szli dalej na Stalingrad, Stanisław ukrywał się przed mobilizacją. Po ponownym powrocie w 1944 roku sowieci przeprowadzali kolektywizację i wszelkimi sposobami, nie wyłączając przymusu, zmuszali rolników do przystąpienia do kołchozu. Nakazywali nawet pisanie próśb o przyjęcie całych rodzin do kołchozu z własnymi gruntami i inwentarzem. Gdy się mieszkańcy sprzeciwiali, NKWD-owiec wyciągał rewolwer i krzyczał, że wywiozą takich na Sybir, a to wywoływało zrozumiały lęk i panikę. Sowieci obiecali płacić jeden kilogram żyta za dniówkę pracy w kołchozie, temu kto wyrobił normę. Ten kto pił z nimi wódkę, to dniówkę-normę wyrabiał. Rozpoczęły się kradzieże. Sowieci kradli co mogli i przepijali wszystko. Rodzinna miejscowość Stanisława - Zadworańce przystąpiła do kołchozu jako ostatnia. Stanisław i jego brat Franciszek nie przystąpili, więc musieli płacić olbrzymie podatki, jako sami prowadzący gospodarstwo.

Po podpisaniu 26 V 1942 roku w Londynie radziecko-brytyjskiego układu o współpracy w wojnie z Niemcami, premier brytyjski Churchill ${ }^{19}$ zaproponował

${ }^{18}$ Wężyk-Widawska, Ksiadz Stanisław Mitkowski, s. 98-99.

${ }^{19}$ Churchill - Sir Winston Leonard Spencer (1874-1965) brytyjski mąż stanu, pisarz, członek Izby Gmin z ramienia Partii Konserwatywnej, następnie Partii Liberalnej. Od 1910 r. zajmował urzędy ministerialne: minister spraw wewnętrznych (1910-11), minister zaopatrzenia wojskowego (1917-18), minister wojny i lotnictwa (1919-21), minister kolonii (1921-22), premier (1940-45), kierował obroną narodową, strategią wojskową i polityką zagraniczną państwa podczas II wojny 
przeniesienie polskich oddziałów wojskowych uformowanych z ZSRR na Bliski Wschód dla wsparcia sił brytyjskich. W sierpniu tego roku 70 tys. osób (40 tys. żołnierzy i oficerów, 4,5 tys. junaków i kobiet ze służb pomocniczych oraz 25,5 tys. ludności cywilnej) przewieziono do Iranu. Jednak wyjazdu do Iranu odmówiła grupa oficerów z ppłk. Zygmuntem Berlingiem na czele, którą Stalin przygotowywał na wypadek wznowienia rekrutacji Polaków. Po powstaniu w lutym 1943 roku w Moskwie Komitetu Organizacyjnego Związku Patriotów Polskich zapowiadającego powstanie wolnej i niepodległej Polski połączonej „braterskimi i sąsiedzkimi" stosunkami z Związkiem Sowieckim, w sierpniu 1943 roku ZPP uzyskał zgodę rządu sowieckiego na formowanie kolejnych jednostek I Korpusu Polskich Sił Zbrojnych w ZSRR, pod dowództwem Zygmunta Berlinga ${ }^{20}$, mianowanego przez Józefa Stalina generałem. Po bitwie pod Lenino jednostki polskie walczące u boku Armii Czerwonej szły na zachód. W marcu tego roku przekształcono I Korpus w 1 Armię Wojska Polskiego liczącą w sumie 78 tys. żołnierzy i oficerów, w którym ponad połowa oficerów i prawie wszyscy generałowie pochodzili z Armii Czerwonej. Gdy ofensywa Armii Czerwonej na Berlin przesuwała się na terytorium Polski wszyscy młodzi szli do armii generała Zygmunta Berlinga. Na wiosnę 1944 roku zorganizowano na ziemiach polskich pobór do wojska. Trzeba było się meldować i stawiać do poboru. Stanisław zdecydował, że do „wojska sowieckiego” w 1 Armii Wojska Polskiego generała Berlinga nie pójdzie. Postanowił się ukrywać w czasie wojny i tak żył do 1958 roku $^{21}$.

światowej i na tym polu wykazał się dużą energią i determinacją w działaniu. Uczestnik konferencji w Teheranie, Jałcie i Poczdamie. Po 1945 r. uważał ZSRR za główne zagrożenie dla świata.

${ }^{20}$ Zygmunt Henryk Berling (1896-1980), ur. w 1896 r. w Limanowej, w latach 1914-1917 żołnierz Legionów Polskich, uczestnik wojny polsko-bolszewickiej, do 1939 r. zawodowy oficer Wojska Polskiego. W obozie jenieckim w Starobielsku został zwerbowany do współpracy z NKWD. Wstąpił do Armii Polskiej tworzonej przez gen. Władysława Andersa i został mianowany dowódcą Polskich Sił Zbrojnych w ZSRR. Po dezercji z Wojska Polskiego skazany został 20 IV 1940 r. przez polski Sąd Polowy na karę śmierci i pozostał w ZSRR. W 1943 r. mianowany przez Józefa Stalina dowódcą 1 Dywizji Piechoty im. T. Kościuszki, w 1944 r. dowódcą I Armii WP. Berling zatwierdzał wyroki śmierci na żołnierzach swojej armii podejrzanych o współpracę z podziemiem niepodległościowym. Od 22 VII 1944 r. był zastępcą Naczelnego Dowódcy Wojska Polskiego w stopniu generała dywizji, a dwa tygodnie później rozkazem Stalina został odwołany ze stanowiska dowódcy 1 AWP, co praktycznie zakończyło polityczną karierę Berlinga w ramach najwyższych struktur państwowych tworzonych przez ZSRR w Polsce. Zmuszony do podjęcia studiów na Wyższej Wojskowej Akademii Sił Zbrojnych im. K. Woroszyłowa w Moskwie. Rząd w Warszawie wraz z dowództwem Wojska Polskiego wyraziły w lutym 1947 r. zgodę na jego powrót do kraju dopiero po wyborach do Sejmu Ustawodawczego (sfałszowanych przez komunistów). W 1947 r. organizował Akademię Sztabu Generalnego i powołany na stanowisko komendanta tej uczelni wojskowej, w tym samym roku został odwołany. Ponownie kierował ASG w latach 1948-1953. W tym okresie w ramach czystek wśród kadr naukowych uczelni aresztowano przedwojennych oficerów Wojska Polskiego (m.in. gen. Heliodora Cepę, płk. Jana Rzepeckiego). Po przejściu na emeryturę w 1953 r. ze względu na stan zdrowia pracował w Ministerstwie Rolnictwa. Od 1956 r. prezes Polskiego Związku Łowieckiego, od 1970 r. Inspektor Generalny Łowiectwa, w 1963 r. wstąpił do PZPR. Zmarł w 1980 r. w Konstancinie-Jeziornej. Bargiełowski D., Konterfekt renegata, Komarów 1996.

${ }^{21}$ W. Roszkowski, Historia Polski 1914-1996, Warszawa 1997, s. 99, 111, 120, 123; Relacja koad. S. Żukowskiego z dnia 7 II 2003 r. w Oświęcimiu (zb. aut.). 


\section{Zaangażowanie $\mathbf{w}$ życie parafii - nauczyciel religii}

W Litewskiej SRR do 1948 roku nie było uchwał rządu republikańskiego regulujących sprawy wyznaniowe, poza przepisem Konstytucji z 1940 roku mówiącej o rozdziale Kościoła od państwa. Wraz z nasileniem represyjnego kursu polityki wyznaniowej, realizowanego przez republikański rząd litewski mimo braku stosownych uchwał, ale zgodnie z powszechną w ZSRR praktyką, wprowadzono drastyczne ograniczenia życia religijnego i represje przez wydanie odpowiednich aktów prawnych. I tak dnia 19 VI 1948 roku Prezydium Rady Najwyższej Litewskiej SRR wydało dekret „O nacjonalizacji domów modlitwy i zabudowań kościelnych, a także domów mieszkalnych należących do wspólnot religijnych”. Dekret dopuszczał nacjonalizację kościołów, klasztorów wraz z zabudowaniami, niezależnie od ich wielkości oraz określał ich przekazanie nieodpłatnie i na czas nieokreślony wspólnotom religijnym zarejestrowanym w urzędzie pełnomocnika Rady ds. Kultów Religijnych ${ }^{22}$. Dekret ten był wymierzony głównie w Kościół katolicki na Litwie, który do połowy 1948 roku skutecznie bojkotował nakaz rejestracji parafii przez tworzenie tzw. dwudziestek. Rejestracja katolickich wspólnot religijnych na gruncie litewskim nastąpiła po wydaniu dnia 13 IX 1948 roku przez Radę Ministrów Litewskiej SRR uchwały „O rejestracji wspólnot religijnych i zakazie zbiorowego nauczania dzieci religii ${ }^{23}$.

Ponieważ na terenach radzieckich, także na Wileńszczyźnie, księża nie mogli od 1948 roku uczyć dzieci religii, pełniły tę posługę w parafiach miejscowe zelatorki żywego różańca świętego. W Kalwarii Wileńskiej podjęła te obowiązki matka Stanisława - Zofia. Gdy matka zachorowała, jej obowiązki w zastępstwie przejął syn Stanisław, bez żadnego w tym kierunku przygotowania. Co prawda należał do organizacji religijnej w Wilnie - Stowarzyszenia Młodzieży Polskiej, później Katolickiego Stowarzyszenia Młodzieży Męskiej, a to zaangażowanie W młodzieżowej organizacji katolickiej dało mu pewne przygotowanie do podjęcia obowiązków nauczyciela religii. W tej intencji uprzednio udał się pieszo do Ostrej Bramy i prosił Matkę Bożą, by mu dała odpowiednie natchnienie i potrzebne łaski, a uczącym się miłość do Pana Jezusa. On sam jako niedoświadczony katecheta starał się z czystym sercem i w stanie łaski uświęcającej rozpoczynać katechezę. Sądził bowiem, że winien sam najpierw Pana Jezusa pokochać, aby następnie „przekazywać” Go uczącym się dzieciom. Na katechezę przychodziły gromady chłopców i dziewcząt. Pewnego razu przyjechał ks. Tadeusz Hop-

${ }^{22}$ Przy Radzie Komisarzy Ludowych ZSRR powstała w maju 1944 r. Rada ds. Kultów Religijnych, która w swej gestii miała nieprawosławne wyznania religijne, w tym także sprawy Kościoła katolickiego. W republikach związkowych, autonomicznych i obwodach utworzono urzędy pełnomocników Rady. I. Mikłaszewicz, Polityka sowiecka wobec Kościoła katolickiego na Litwie 19441965, Warszawa 2001, s. 27.

${ }^{23}$ Niezarejestrowane wspólnoty religijne podlegały rozwiązaniu a ich kościoły zamknięciu. Uchwała nie dopuszczała organizowania przez księży spotkań dzieci, młodzieży, kobiet, także spotkań poświęconych refleksji nad Pismem Świętym. Mikłaszewicz, Polityka sowiecka wobec Kościota katolickiego na Litwie, s. 28-29. 
$\mathrm{pe}^{24}$, salezjanin i proboszcz z Rudnik, by przygotowywane przez 6 tygodni przez Stanisława dzieci egzaminować. Zdali wszyscy doskonale. W następnych latach nie zawsze przyjeżdżał ks. Hoppe na egzamin, bo wiedział, że Stanisław dobrze przygotowuje. Tak Stanisław katechizował przez 10 lat, do momentu wyjazdu do Polski. Mimo obowiązującego zakazu katechizowania dzieci przez kapłanów, w każdej parafii a nawet w każdej wiosce znalazł się ktoś ze świeckich, kto prowadził katechizację ${ }^{25}$.

Działo się to w czasie, gdy władze komunistyczne zakazały uczenia modlitwy dzieci i młodzieży oraz uczęszczania do kościoła w czasie małoletności. Tymczasem w Kalwarii Wileńskiej organizowana była I Komunia święta w parafii $\mathrm{z}$ odświętnie ubranymi dziećmi.

W 1949 roku ks. Miłkowski przeżył pożar i został obrabowany - prawdopodobnie w czasie napadu partyzanckiego. Tego roku na Boże Ciało władze komunistyczne usunęły z Kalwarii Wileńskiej ówczesnego proboszcza ks. Stanisława Miłkowskiego, który w ciągu 24 godzin musiał opuścić probostwo ${ }^{26}$, pozbawiając go tzw. sprawki do spełniania funkcji kapłańskich. Otrzymując nakaz opuszczenia dotychczasowego miejsca zamieszkania, nie mógł też zamieszkać w Wilnie. Udał się do Trok, gdzie proboszczem był życzliwy mu ks. Ludwik Kluk. Tam poważnie zaniemógł i na drugi dzień został przewieziony do szpitala w Wilnie, gdzie przebywał dwa tygodnie. Ze względu na chorobę i możliwość bliskości pomocy lekarskiej ks. Miłkowski zamieszkał w Nowej Wilejce, na co władze wyraziły zgodę. Nieco wcześniej władze komunistyczne znacjonalizowały w Kalwarii dom rekolekcyjny. Gdy ksiądz proboszcz odchodził, na pożegnanie powiedział: „ratujcie dzieci jak możecie". Wówczas cały kościół płakał. Od tego czasu rozpoczynał się najcięższy okres w historii pątniczego sanktuarium w Kalwarii Wileńskiej. Mimo to w ciągu jeszcze kilkunastu lat ciągnęły ze wszystkich stron do Kalwarii liczne pielgrzymki ${ }^{27}$.

Na miejsce ks. Miłkowskiego przybył z Rudnik ks. Tadeusz Hoppe. Stanisław Żukowski wspomina tego duszpasterza z wielką atencją. Ks. Hoppe lubił porządek ,jak Prusak”, głosił piękne kazania. Tu ks. Tadeusz oddawał się pracy duszpasterskiej jako kustosz sanktuarium pielgrzymkowego na całą Wileńszczyznę. Do Kalwarii przybywały wówczas liczne pielgrzymki. Każdą taką grupę ks. Hoppe witał, wygłaszał naukę katechizmową lub kazanie. Nawet kilkanaście kazań dziennie wygłaszał. W ogóle kazania ks. Hoppe były bogate w treści teologiczne i katechizmowe, co bardzo chwytało za serca słuchaczy. Stanisław ka-

${ }^{24}$ Jeden z 11 salezjanów (10 księży i jeden koadiutor), którzy po 1945 r. pozostali na terytorium ZSRR by służyć posługą kapłańską tamtejszym katolikom. W. W. Żurek, "Jeńcy na wolności». Salezjanie na terenach byłego ZSRR po drugiej wojnie światowej, Kraków 1998, s. 77-109.

${ }^{25}$ Relacja koad. S. Żukowskiego z dnia 7 II 2003 r. w Oświęcimiu (zb. aut.).

${ }^{26}$ Wyszło wówczas zarządzenie władz, że byli wojskowi mieli zakaz wstępu do miasta Wilna. Proboszcz kalwaryjski ks. Miłkowski przenocował u siebie wojskowego, ten przyszedł następnie do Wilna gdzie został zatrzymany. Za ten kontakt proboszcz otrzymał nakaz opuszczenia parafii. Wężyk-Widawska, Ksiądz Stanisław Miłkowski, s. 103.

${ }^{27}$ Tamże, s. 103. 
zania ks. Hoppe streszczał własnoręcznie na własny użytek ${ }^{28}$. Oczywiście władze komunistyczne podsyłały szpicli by słuchali kazań głoszonych przez księży. Za takie kazania „polityczne” ks. Hoppe został z Kalwarii usunięty w 1954 roku, chociaż o dziwo, miejscowi komuniści byli przeciwni decyzji władz ds. kultów religijnych. O tym zdecydowały czynniki na wyższym szczeblu. Ks. Hoppe udał się na proboszcza do podwileńskich Ławaryszek. Charakteryzując sylwetkę tego salezjanina Stanisław kończył słowami: „to był legendarny ksiądz”. Poprzez niego Stanisław poznał salezjanów, do których ostatecznie wstąpił. Po odejściu ks. Tadeusza, Kalwaria Wileńska przeżywała regres i już nigdy nie dźwignęła się. Dopomogły temu restrykcyjne decyzje władz komunistycznych. Tak wspomina i komentuje tamte lata ks. prałat Józef Obrębski ${ }^{29}$ z Mejszagoły. Na miejsce ks. Hoppe w Kalwarii administratorem parafii został wyznaczony ks. Stanisław Woronowicz $(1906-1973)^{30}$.

W czasie pracy duszpasterskiej w Kalwarii Wileńskiej ks. Tadeusz Hoppe pochował zmarłego w 1950 roku Władysława Żukowskiego, brata Stanisława ${ }^{31}$.

\section{Powołanie salezjańskie}

Pomimo ciągłego pragnienia poświęcenia się Bogu jako zakonnik, Stanisław nie mógł tego planu zrealizować. Do klasztoru niepokalanowskiego nie mógł wrócić z powodu granicy na Bugu. Wileńszczyzna znalazła się w granicach Litewskiej Republiki Radzieckiej, więc w państwie rządzonym przez komunistów. I to wydawało mu się wówczas przeszkodą nie do pokonania. Ponadto w 1950 roku zmarł jego brat Władysław i Stanisław opiekował się chorą matką, która w ciągu ostatnich trzech lat życia nie opuszczała łóżka. Należało gospodarstwo prowadzić i opiekować się chorą, tym bardziej że nikogo z krewnych nie mógł prosić o pomoc, bo matka chora była na gruźlicę. Gdy lekarze sowieccy odmówili w 1956 roku leczenia jej w szpitalu mówiąc: „co wy chcecie, jest stara, to jej czas umierać", Stanisław leczył ją prywatnie nie żałując kosztów i poświęcenia. Gdy dnia 13 I 1958 roku zmarła jego matka, został sam jeden na gospodarce. Pochowana została prawdopodobnie przez ks. Stanisława Woronowicza na cmentarzu parafialnym w Kalwarii Wileńskiej w mogile zmarłego w 1937 roku męża Piotra oraz zmarłych wcześniej dwóch synów: Jana († 1934) i Władysława $(† 1950)^{32}$.

${ }^{28}$ M.in. korzystał z nich w katechezie. Przed wyjazdem do Polski swoje zapiski spalił obawiając się represji władz. Żurek, "Jeńcy na wolności", s. 87-90; Relacja koad. S. Żukowskiego z dnia 7 II 2003 r. w Oświęcimiu (zb. aut.).

${ }^{29}$ Relacja ks. J. Obrębskiego z 11 XI 1996 r. - Mejszagoła k. Wilna (zb. aut.).

${ }^{30}$ Żurek, "Jeńcy na wolności», s. 87, 90, tenże, Możliwości i formy duszpasterzowania salezjanów w powojennej rzeczywistości na terenach europejskich republik radzieckich, Archiwa Biblioteki i Muzea Kościelne 87 (2007), s. 327-328.

${ }^{31}$ W. W. Żurek, Ksiadz Tadeusz Hoppe SDB (1913-2003), w: Prorocy Europy ŚrodkowoWschodniej XX wieku, red. S. C. Napiórkowski, Lublin 2009, s. 237-238.

${ }^{32}$ Pan Stanisław przesłał bratanicy pieniądze na postawienie pomnika na grobie rodziców i braci. Następnie w 2002 r. odwiedził rodzinne strony i żyjącą rodzinę, tj. dwie bratanice z ich rodzinami. ASIK, b. sygn., Zespół: zmarli współbracia. Teczka personalna koad. Żukowskiego Stanisława, 
Dopiero po śmierci matki Stanisław zdecydował o wyjeździe do Polski jako tzw. repatriant, planując ponowne wstąpienie do zakonu franciszkańskiego. Na początek rozpoczął starania o wyrobienie dokumentu tożsamości, którego do tej pory nie posiadał, książeczki wojskowej także nie miał. Do tego potrzebna była metryka urodzenia i zaświadczenie o zamieszkaniu. Metrykę urodzenia miał wydaną przed wojną. Sekretarzem gminy (sielsowietu) - był na tym stanowisku nowy urzędnik. Nie orientując się dokładnie w skomplikowanej procedurze wydał Stanisławowi zaświadczenie potwierdzające jego zamieszkanie w Zadworańcach $\mathrm{z}$ adnotacją, że nie zalega $\mathrm{z}$ podatkami. Metrykę przetłumaczono na język rosyjski.

Stanisław kontynuował dalsze starania o wyrobienie dowodu osobistego na milicji - tamtejszego NKWD. Spotkał tam pracującego młodzieńca, którego w 1949 roku uczył religii i to mu bardzo pomogło. Tam złożył podanie o wyrobienie dokumentu tożsamości w języku rosyjskim. Po odbiór miał się zgłosić za kilka miesięcy. Gdy upłynął wyznaczony termin, planował udać się po odbiór dokumentu tożsamości. Po nabożeństwie „Bożej opieki” w Ostrej Bramie w Wilnie Stanisław planował zdążyć na ulicę Trocką po odbiór dokumentu. Wsiadł do zupełnie innego autobusu - który jechał do Wielkiej Łapy - pięć kilometrów w zupełnie innym kierunku, zamiast na ulicę Trocką. Zorientował się po niewczasie, zawrócił i z dużym opóźnieniem dotarł na milicję gdy tymczasem pracownicy wychodzili po pracy do domu. Naczelnika NKWD już nie było. Mimo wszystko poprosił o wydanie dokumentu tożsamości. Sekretarka poleciła podpisanie odbioru dokumentu, uiszczenie odpowiedniej kwoty i dowód osobisty wydała, nie sprawdzając dokładnie personaliów Stanisława. Gdyby był wówczas naczelnik, to z pewnością dokumentu by nie otrzymał, a Stanisława najprawdopodobniej wysłano by na Sybir. Chodziło o to, że gdy z więzienia radzieckiego uciekł aresztowany były AK-owiec, wówczas na ulicy aresztowano wielu mężczyzn. Będąc na milicji Stanisław taką taktykę władz sowieckich ocenił po swojemu czyli skrytykował. Po wypowiedzeniu swojego zdania na ten temat, usłyszał odpowiedź: „jak my aresztujemy 1000, to w tej masie będzie i poszukiwany zbieg" ${ }^{\prime 3}$.

Posiadając dowód osobisty Stanisław złożył wymagane dokumenty na wyjazd z Litewskiej Socjalistycznej Republiki Radzieckiej do Polskiej Rzeczypospolitej Ludowej jako tzw. repatriant. Wówczas wyszła kolejna sprawa i zaniedbanie ze strony Stanisława - książeczki wojskowej, której nie posiadał. Uzyskał zarzut: wszyscy mieli obowiązek być w wojsku, a ty nie byłeś, więc byłeś szpiegiem, a taki winien kończyć na Sybirze. Po wielu kłopotach i zabiegach otrzymał dnia 26 I 1959 roku na milicji (MWD) ostatecznie pozwolenie na wyjazd do Polski z terminem do 31 III 1959 roku opuszczenia Wileńszczyzny. Od strony prawnej gotów był do wyjazdu. Musiał go jednak odłożyć ze względu na chorobę i operację, której musiał się poddać. Cierpiał na niedrożność jelit i przeprowadzono mu resekcję jelita. Także długie leczenie wstrzymało jego wyjazd do dnia 8 VIII 1959 roku. Uprzednio w ciągu ośmiu dni musiał zlikwidować przed wyjazdem

Życiorys Stanisława Żukowskiego napisany w Kopcu dnia 8 V 1960 r., St. Żukowski do Księży Salezjanów z 18 IX 1958 r.-Zadworańce.

${ }^{33}$ Relacja koad. S. Żukowskiego z dnia 7 II 2003 r. w Oświęcimiu (zb. aut.). 
gospodarstwo rolne ${ }^{34}$. Za sprzedaną krowę i świnie kupił sobie wyprawkę i po kilku dniach był gotowy na wyjazd ${ }^{35}$.

Równocześnie ze staraniami na wyjazd rozpoczął starania o powtórne przyjęcie do Zakonu św. Franciszka, jako przedwojenny nowicjusz. Ze względu na przekroczony wiek 35 lat nie został przyjęty. Nie zniechęcając się przedkładał swoją prośbę w innych zakonach. Od ojców paulinów, kapucynów, bernardynów i karmelitów otrzymał odpowiedź odmowną. Od ojców dominikanów i kamedułów nie otrzymał żadnej odpowiedzi na przedłożoną prośbę. Ostatecznie we wrześniu 1958 roku napisał do księży salezjanów w Krakowie i od tego czasu rozpoczęła się jego korespondencja z salezjanami. W odpowiedzi na ten list, z dnia 26 IX 1958 roku, otrzymał Stanisław zaproszenie na przyjazd do Polski. Wysyłając życzenia noworoczne na 1959 rok ówczesnemu przełożonemu (u salezjanów nazywanego inspektorem) Prowincji św. Jacka w Krakowie - ks. Józefowi Nęckowi proponował, że może przywieźć ze sobą samochód osobowy marki Wołga, który otrzymał w spadku od ks. Tadeusza Hoppe; ks. Hoppe w grudniu 1958 roku wyjechał z podwileńskich Ławaryszek do pracy duszpasterskiej w Odessie nad Morzem Czarnym ${ }^{36}$.

W odpowiedzi na kolejny list z 2 III 1959 roku przełożony prowincji - ks. Nęcek polecił dnia 11 III 1959 roku sekretarzowi przesłanie Stanisławowi życzeń wielkanocnych z informacją, że będzie przyjęty na aspiranta-koadiutora ${ }^{37}$.

Przed wyjazdem do Polski Stanisław odprawił rekolekcje wielkopostne w rodzinnej parafii, zakończone w Niedzielę Palmową 1959 roku. Pożegnawszy się bliskimi i sąsiadami dotarł do Wilna i dalej ruszył pociągiem do Polski. Kiedy powiedział na granicy, że jedzie na stałe do Polski, poddany został bardzo szczegółowej kontroli granicznej. Na granicy był świadkiem niecodziennego zdarzenia ze strzelaniną. Ktoś jechał ukryty pod wagonem kolejowym usiłując nielegalnie

${ }^{34}$ Pozostawił swoją nieruchomość: dom drewniany parterowy i oborę oraz przylegający doń sad owocowy o powierzchni 0,5 ha gruntu w Zadworańcach. W testamencie spisanym przed pierwszą profesją zakonną dnia 2 VII 1961 r. zapisał całość bratu Franciszkowi, zamieszkałemu tamże, $\mathrm{z}$ tym, że spłaci on drugiemu bratu Witoldowi, zamieszkałemu we wsi Taranda (pow. Wilno) jedną czwartą część tego majątku, to jest równowartość 3.500 rubli z 1959 r., a w razie zwrotu 6 ha gruntów zabranych przez rząd Związku Radzieckiego, zapisał Stanisław po równej części swoim braciom: Witoldowi i Franciszkowi. ASIK, b. sygn., Zespół: zmarli współbracia. Teczka personalna koad. Żukowskiego Stanisława, Testament St. Żukowskiego z 2 VII 1961 r. - Kopiec.

${ }^{35}$ ASIK, b. sygn., Zespół: zmarli współbracia. Teczka personalna koad. Żukowskiego Stanisława, St. Żukowski do Księży Salezjanów z 2 III 1959 r. - Zadworańce, Świadectwo lekarskie dra Edwarda Radosławskiego o Stanisławie Żukowskim z dnia 7 V 1960 r.

${ }^{36}$ Do Polski mógł przywieść 6.000 rubli poprzez Gosbank w Wilnie, a w Krakowie Narodowy Bank Polski wypłaci 8.977,20 złotych, licząc za 100 rubli - 149,62 złotych. Stanisław pytając czy wystarczy tych pieniędzy na kupno koniecznej wyprawy w Polsce, proponował przełożonym, że za te pieniądze może kupić coś koniecznego dla salezjanów, co w Związku Sowieckim jest tańsze niż w Polsce, a w zamian salezjanie kupią mu konieczną wyprawkę. ASIK, b. sygn., Zespół: zmarli współbracia, Teczka personalna koad. Żukowskiego Stanisława, St. Żukowski Księży Salezjanów z 2 III 1959 r. - Zadworańce.

${ }^{37}$ ASIK, b. sygn., Zespół: zmarli współbracia. Teczka personalna koad. Żukowskiego Stanisława, St. Żukowski do Księży Salezjanów z 28 IX 1958, 2 III 1959 r. - Zadworańce. 
przekroczyć granicę. Wkrótce za granicą wyskoczył ale został schwytany przez służby graniczne.

Szczęśliwie dnia 8 VIII 1959 roku przybył Stanisław taksówką z dworca kolejowego w Krakowie na ul. Konfederacką 6, gdzie mieściła się siedziba przełożonego salezjanów Prowincji św. Jacka. Gdy powiedział, że przyjechał z Rosji, nie chciano z nim rozmawiać. Po okazaniu pocztówki z życzeniami wielkanocnymi, jaką otrzymał wcześniej z Polski, uwierzono mu i został przyjęty przez salezjanów.

Na początek miał poważne problemy z uzyskaniem dowodu tożsamości i z zameldowaniem się w Krakowie. Zdecydował się napisać skargę do naczelnika ds. repatriacji, wyjaśniając, że nie chcą go zameldować, a u salezjanów ma zapewnione wszystko, w tym i mieszkanie. W odpowiedzi naczelnik skierował pismo do milicji w Krakowie, z zapytaniem, dlaczego robią trudności Stanisławowi z zameldowaniem? Wówczas wezwano go na milicję i tam podano mu kartkę, aby napisał, że nie starał się o dowód osobisty. Takiej prośbie-poleceniu zdecydowanie odmówił. Argumentował: byłem potrzebny w 1939 i w 1944 roku - więc tego nie podpiszę. Na drugi dzień miał się zgłosić po odbiór dowodu tożsamości, który otrzymał, a to dawało możliwość zameldowania się i otwierało drogę do legalnego pobytu w kraju. Urzędnicy państwowi radzili mu pojechać na Ziemie Odzyskane - do Wrocławia, ale nie chciał słuchać ich $\operatorname{rad}^{38}$.

$\mathrm{Na}$ rozpoczęcie nowicjatu zakonnego czekał rok. Przełożeni zatrzymali Stanisława w Krakowie i tu odprawiał aspiranturę. Został przyjęty do klasy VIII Szkoły Powszechnej w Krakowie, pracował równocześnie na gospodarstwie rolnym w zakładzie salezjańskim w Krakowie, przy ul. Tynieckiej 39, na „Łosiówce”. Aspiranturę kontynuował od 17 II 1960 roku w Zakładzie Salezjańskim w Kopcu koło Częstochowy gdzie mieścił się nowicjat salezjański, pracując na gospodarstwie i w ogrodzie. W Kopcu dnia 1 VII 1960 roku 47 letni Stanisław rozpoczął $\mathrm{w}$ grupie ponad czterdziestu kandydatów nowicjat jako brat zakonny. Przełożonym domu zakonnego Świętego Krzyża w Kopcu był, młody wiekiem, ks. Zbigniew Bączkowski. Obowiązki magistra nowicjuszów przez kilka tygodni pełnił ks. Alojzy Orszulik. Wprowadzał on kandydatów w życie w zgromadzeniu salezjańskim radośnie, życzliwie i rozumnie. Od samego początku nowicjusze wiedzieli, że ma zastąpić go ks. Andrzej Świda. Wszyscy oczekiwali na jego przybycie do Kopca $\mathrm{z}$ pewnym napięciem. Kiedy podjął pracę formacyjną w nowicjacie, nowicjusze rozpoznawali w nim zdrowe, prawdziwe ojcostwo duchowe i doświadczenie życiowe ${ }^{39}$. Na co dzień okazał się radosny i rzeczowy, życzliwy i wymagający. Obowiązki socjusza pełnił ks. Jerzy Grobelak, a asystentem nowicjuszów kl. Jan Gajer. Ekonomem był ks. Józef Nawara. Neoprezbiterzy: ks. Wiesław Duduś i ks. Józef Grzyb tworzyli wspaniałą wspólnotę duszpasterską i wychowawczą, zapaleni kaznodzieje i życzliwi kapłani wychowawcy.

W prośbie do przełożonego domu nowicjackiego o przyjęcie go do nowicjatu Stanisław napisał: „[...] Pragnę gorąco w nowicjacie nauczyć się prawdziwej po-

${ }^{38}$ Relacja koad. S. Żukowskiego z dnia 7 II 2003 r. w Oświęcimiu (zb. aut.).

${ }^{39} \mathrm{~W}$ czasie II wojny światowej ks. Świda pełnił obowiązki kapelana Wojska Polskiego w armii gen. Władysława Andersa, w randze kapitana. Relacja współnowicjusza Stanisława - ks. Henryka Skórskiego z 29 IX 2011 r. - Wisła (zb. aut.). 
bożności, by potem jako zwykły brat koadiutor w Towarzystwie św. Franciszka Salezego pod opieką Niepokalanej poświęcić się całkowicie służbie Panu Bogu nad uświęceniem własnej duszy i pomóc swą rzetelną pracą tym co poświęcili swe życie pracy nad uświęceniem młodzieży". Ten rocznik był liczny ${ }^{40}$.

Wspólnota nowicjacka była zróżnicowana pod względem wieku i wykształcenia. Na pierwszym miejscu wyróżniali się nowicjusze w sutannach. Było ich trzech, klerycy z Seminarium Duchownego w Przemyślu: subdiakon Stanisław Kulpaczyński, kl. Eugeniusz Muła i kl. Jerzy Harlender. Po nich nowicjusze po maturze, którzy przyszli z tzw. świata oraz nowicjusze - wychowankowie salezjańscy, niektórzy po małej maturze. Do tej wspólnoty należało trzech nowicjuszy z zamiarem pozostania w zgromadzeniu jako bracia. Wśród nich był Stanisław. W styczniu 1961 roku ten rocznik liczył 33 nowicjuszy: 32 kleryków i jeden Stanisław Żukowski, kandydat na brata zakonnego. Dopiero pod koniec nowicjatu współnowicjusze dowiedzieli się, że Stanisław przed wojną był nowicjuszem franciszkańskim w Niepokalanowie. Na co dzień nazywano go, jak to było w zwyczaju w takiej wspólnocie Stasio lub Stanisław ${ }^{41}$.

Przed złożeniem pierwszych trzyletnich ślubów zakonnych w podaniu do dyrektora domu nowicjackiego w Kopcu - ks. Zbigniewa Bączkowskiego napisał: „Wszystko to co usłyszałem na konferencjach Przew. Ks. Magistra oraz na kazaniach i słówkach starałem się wprowadzać praktycznie w codziennym życiu [...] w stałym dążeniu do doskonałości wytrwam aż do śmierci jako zakonnik koadiutor w Towarzystwie św. Franciszka Salezego. Kończący nowicjat salezjański Stanisław na czterech w ciągu roku nowicjackiego opiniowaniach - salezjańskich skrutyniach (8 X 1960, 8 I, 9 IV i 11 VI 1961) otrzymał następujące oceny: A, A, A-, B+. Końcowa charakterystyka jego osoby (z 4 VII 1961) zapisana przez magistra nowicjuszy ks. Andrzeja Świdę brzmiała: „Bardzo pobożny, oczytany, ma nieco ducha franciszkańskiego, obserwant, nieco uparty i nie zawsze posłuszny w pracy, natomiast pracę wewnętrzną prowadzi rzetelnie"42. Ostateczną opinię dla przełożonych prowincji wydała Rada Domu w Kopcu (ks. Zbigniew Bączkowski-dyrektor, ks. Andrzej Świda-magister, ks. Józef Nawara-administrator, ks. Jerzy Grobelak-socjusz, ks. Józef Grzyb) zapisana dnia 11 VI 1961 roku w Kopcu brzmiała: „, Bardzo pobożny, nie przejmuje się pracą i uwagami, nieco uparty, troszczy się o zachowanie Regulaminów, przejęty duchem franciszkańskim" ${ }^{3}$.

${ }^{40}$ ASIK, b. sygn., Zespół: zmarli współbracia. Teczka personalna koad. Żukowskiego Stanisława, Aspirant St. Żukowski do dyrektora ks. Zbigniewa Bączkowskiego z 3 V 1960 r. - Kopiec, Życiorys koad. Stanisława Żukowskiego z dnia 8 V 1960 r.- Kopiec, Ammissione al Noviziato z 25 VI 1960 r. - Cracovia, nr 622/60 (L'ispettore sac. Nęcek Giuseppe); Elenco Generale Della Società di S. Francesco di Sales 1961, vol. 1 Torino 1961, s. 284.

${ }^{41}$ Relacja ks. Henryka Skórskiego z 29 IX 2011 r.- Wisła (zb. aut.).

${ }^{42}$ ASIK, b. sygn., Zespół: zmarli współbracia. Teczka personalna koad. Żukowskiego Stanisława, Relatio iurata magistra nowicjuszów ks. Andrzeja Świdy o nowicjuszu Stanisławie Żukowskim z 5 VII 1961 r. - Kopiec.

${ }^{43}$ ASIK, b. sygn., Zespół: zmarli współbracia. Teczka personalna koad. Żukowskiego Stanisława, Alla professione religiosa triennale I. z 11 VI 1961 r. - Kopiec (opinia Rady Domu), z 14 VI 1961 r.- Kraków (opinia Rady Inspektorialnej). 
Pierwszą profesję w zgromadzeniu salezjańskim, czasową i trzyletnią, złożył Stanisław dnia 16 VII 1961 roku w Kopcu na ręce ówczesnego inspektora Prowincji św. Jacka ks. Józefa Nęcka. Ponowił profesję czasową na drugie trzechlecie dnia 9 VIII 1964 roku w Kopcu na ręce inspektora ks. Adama Cieślara. Profesję wieczystą dnia 2 VIII 1967 roku w Kopcu przyjmował od koad. Stanisława Żukowskiego ks. Józef Król, jako przełożony prowincji krakowskiej ${ }^{44}$.

Po złożeniu pierwszych ślubów od 18 VII 1961 roku pracował Stanisław w domu salezjańskim w Lublinie w dzielnicy Kalinowszczyzna. Tam również przeznaczony został do pracy w ogrodzie. W roku następnym skierowany został do Krakowa na Dębniki (ulica Konfederacka 6). Tu od 27 VIII 1962 roku przejął obowiązki kościelnego w Parafii św. Stanisława Kostki. W parafii dębnickiej pracował przez cztery lata. Od 21 VIII 1967 roku przełożeni skierowali koad. Żukowskiego do Marszałek, poczta Bukownica (Wielkopolska), gdzie przez dwa lata pełnił obowiązki kościelnego, gospodarza a w okresie zimowym także palacza w centralnym ogrzewaniu. Od lata 1969 roku rozpoczął pracę w Zakładzie im. Ks. Bosko w Oświęcimiu. Najpierw podjął funkcję kościelnego, następnie portiera zakładowego ${ }^{45}$.

Na pogrzeb brata Franciszka na Litwie w 1963 roku Stanisław nie pojechał. Ówczesny proboszcz Parafii św. Stanisława Kostki i dyrektor na Dębnikach w Krakowie ks. Wawrzyniec Kapczuk, pod nieobecność księdza inspektora, nie zezwolił mu na wyjazd. Gdy po trzech dniach wrócił inspektor, wówczas na wyjazd było już za późno. I to było opatrznościowe. Stanisław zapisany był na czarnej liście komunistycznych władz Litewskiej Socjalistycznej Republiki Radzieckiej. A w przypadku pojawienia się na terenie Republiki Litewskiej zostałby najprawdopodobniej aresztowany ${ }^{46}$.

W życiu salezjańskim dał się poznać jako człowiek pełen radości i optymizmu salezjańskiego. Już w czasie nowicjatu wiekiem był starszy od swoich współnowicjuszy, którzy zawsze go szanowali, ustępowali jako starszemu i odnosili się do niego z należnym szacunkiem. Postrzegany był przez młodszych od siebie kandydatów do kapłaństwa i zgromadzenia jako pogodny na twarzy i darzący wszystkich serdecznym uśmiechem. Nie ma w tych słowach odrobiny przesady,

${ }^{44}$ Archiwum Generalne Salezjanów w Rzymie (dalej: ASC) - C 11.839, Ammissione al noviziato il. Żukowski Stanisław (N. 622/60) Cracovia 11 XII 1960, Professione religiosa (triennali I) coad. Żukowski Stanisław (Kopiec N. 8819/61) wyd. Cracovia 24 VIII 1961, Professione religiosa (triennali II) coad. Żukowski (N. 8939/64) wyd. Cracovia 14 VIII 1964, Professione religiosa (perpetui) coad. Żukowski Stanisław (N. 14/67/) wyd. 2 VIII 1967; ASIK, b. sygn., Zespół: zmarli współbracia, Teczka personalna koad. Żukowskiego Stanisława, Podanie (do dyrektora - ks. Zbigniewa Bączkowskiego) nowicjusza St. Żukowskiego o dopuszczenie do pierwszych ślubów trzyletnich z 5 V 1961 r. - Kopiec, Alla professione religiosa triennale II. z 10 VI 1964 r. - Kraków (opinia Rady Domu), z 22 VI 1964 r. - Kraków (opinia Rady Inspektorialnej).

${ }^{45}$ ASIK, b. sygn., Zespół: zmarli współbracia. Teczka personalna koad. Żukowskiego Stanisława, Opinia i dopuszczenie do ślubów wieczystych koad. St. Żukowskiego z 3 VI 1967 r. - Marszałki, List posłuszeństwa dla koad. St. Żukowskiego o zmianie miejsca zamieszkania i pracy w zgromadzeniu z Lublina do Krakowa (ul. Konfederacka 6) z dnia 10 VII 1962 r. - Kraków (nr 829/62).

${ }^{46}$ ASIK, b. sygn., Zespół: zmarli współbracia. Teczka personalna ks. Wawrzyńca Kapczuka, Ks. Bronisław Piróg (dyrektor), Wspomnienie pośmiertne o śp. ks. Wawrzyńcu Kapczuku, s. 2. 
że zawsze budował innych swą pobożnością. W chwilach wolnych udawał się w ciągu dnia na nawiedzenie Najświętszego Sakramentu do kaplicy św. Jacka na podwórzu zakładowym w Oświęcimiu lub do wewnętrznej kaplicy zakładowej, gdzie spędzał dłuższe chwile na medytacji i modlitwie, głównie na różańcu świętym $^{47}$.

Gdy na to pozwalały siły fizyczne, pracował. Z powierzanych mu obowiązków i prac wywiązywał się sumiennie. Do ostatnich miesięcy swojego życia obecny był wśród zakładowych wychowanków. Chętnie z nimi spędzał rekreację i wolny czas. Grywał z wychowankami w szachy, zazwyczaj wygrywając.

Jego życie duchowe opierało się na modlitwie, częstej spowiedzi świętej i ukochaniu Eucharystii. Zakonną wolę nawracania koad. Żukowski odnawiał w comiesięcznym dniu skupienia („ćwiczenie dobrej śmierci”) i w dorocznych rekolekcjach. Jak dla każdego salezjanina, były to chwile duchowego odrodzenia, które ks. Bosko uważał za część podstawową i syntezę wszystkich praktyk pobożności: „Dają one wspólnocie i każdemu salezjaninowi szczególną sposobność słuchania Słowa Bożego, rozpoznawania woli Boga i oczyszczania serca. Ten czas przywraca naszej duszy głęboką jedność w Jezusie Chrystusie i ożywia nasze oczekiwanie na jego powtórne przyjście"48.

Coroczne rekolekcje odprawiał Stanisław zazwyczaj w czasie serii dla współbraci w Oświęcimiu lub w domach sąsiednich, zazwyczaj w Seminarium Duchownym Krakowie: od 9-14 VII 1973 roku w Oświęcimiu, od 8-13 VIII 1974 roku w Krakowie na „Łosiówce”, od 5-10 VII 1976 roku w Krakowie na „Łosiówce”, od 7-12 VII 1984 roku w Oświęcimiu, od 1-6 VII 1985 roku w Oświęcimiu ${ }^{49}$.

Brał udział $\mathrm{w}$ organizowanych od czasu do czasu zjazdach formacyjnych dla braci zakonnych zakonów męskich, wspólnie z innymi koadiutorami (m.in. Wilhelmem Miemcem, Brunem Fijałkowskim - 29 XII 1973 roku w Krakowie). Wziął także udział w XXIII pielgrzymce braci zakonnych na Jasną Górę, która odbyła się w dniach 9-10 III 2005 roku. Hasło pielgrzymki braci zakonnych tego roku brzmiało: „Bracia zakonni w służbie Chrystusowi Eucharystycznemu poprzez swoje oddanie dla pracy w Kościele"

Pracując w zakładzie oświęcimskim koad. Żukowski udawał się od czasu do czasu z pielgrzymką do Częstochowy. W 1981 roku na święto Matki Bożej Częstochowskiej (26 sierpnia) koad. Stanisław pojechał pociągiem z Oświęcimia. Po powrocie jego „rozliczenie” z otrzymanych od dyrektora zakładu - ks. Kazimierza Parciaka pieniędzy(100 złotych) na wyjazd miało trzy pozycje: podróż, kanap-

${ }^{47}$ Relacja ks. Stanisława Kulpaczyńskiego z 4 VIII 2010 (zb.aut.).

${ }^{48}$ Konstytucje Towarzystwa św. Franciszka Salezego, w: Konstytucje i Regulaminy, Rzym 1986, art. 91 (Konst.).

${ }^{49}$ Archiwum Zakładu Salezjańskiego w Oświęcimiu (dalej: AZSO), b. sygn., Kronika zakładu od 1 I 1973 - 3 IX 1977, zapis z 9 VII 1973, 8 VIII 1974, 5 VII 1976; Kronika zakładu 1 I 1978 - 2 II 1996, zapis z 7 VII 1984, 1 VII 1985.

${ }^{50}$ ASIK, b. sygn., Zespół: zmarli współbracia. Teczka personalna koad. Żukowskiego Stanisława, Sekretarz isnpektorii w Krakowie - ks. Jan Lis do koad. St. Żukowskiego w Oświęcimiu z dnia 1 II 2005 r. - Kraków (L.dz. 18/KO/2004); AZSO, b. sygn., Kronika zakładu 1 I 1973 - 3 IX 1977, zapis z 29 XII $11973 \mathrm{r}$. 
ka, ofiara dla biedaka proszącego (skromna kwota). Z pozostałych mu pieniędzy zwrócił przełożonemu kilka złotych. Już w opinii przy dopuszczeniu do złożenia ślubów wieczystych w 1967 roku został oceniony m.in.: w praktykowaniu ślubu ubóstwa jako wzorowy ${ }^{51}$.

W jednym ze swoich listów do współbrata ukazał humorystycznie niektóre momenty swego życia zakonnego, porównując je z poprzednim okresem:

Przewielebny Księże! Przesyłam serdeczne „Bóg zapłać” za pamięć i życzenia Imieninowe a najwięcej za modlitwy - abym zbawił duszę swoją.

W przeddzień 13 listopada przywędrowała do mnie i złożyła życzenia „pani grypa” obdarowując pigułkami, termometrem i przymusowym wypoczynkiem. Ale dzięki P. Bogu wszystko przeminęło szczęśliwie i znów wróciłem do pracy. Wstaję codziennie o 4.30, o 5.15 otwieram Kościół, zostaję na Mszy św. o 6.00, potem na Jutrznię i Rozmyślanie do kaplicy. O 7.15 do jadalni i na pocztę.

Przed wojną ani razu w życiu nie widziałem jednego tysiąca złotych - teraz co dzień obracam milionami.

Moi dziadkowie uprawiali pole sochami, żyli w kurnych chatach - mój ojciec wybudował dom i postawił piec z kominem, kupił pierwszy pług żelazny - nowość we wsi! Teraz ja mieszkam w pięknym pokoju z podłogą parkietową, meblościankami, własną łazienką i prysznicem.

Przed wojną słuchałem radia własnego pomysłu na kryształka, który sam wyrabiałem i słuchawki. Teraz mogę słuchać radia z całego świata na rozmaite zakresy fal.

Do lekarza udawało się w bardzo ciężkim stanie a do szpitala w stanie beznadziejnym. Najczęściej na wsi ludzie umierali własną śmiercią, bez pomocy lekarzy - bo „przyszedł czas” na śmierć. Tu mam lekarzy na zawołanie o każdej porze dnia i nocy, zapewnione miejsce w najlepszych szpitalach.

A więc spełniło się jak powiedziano w Ewangelii: „Kto opuści wszystko i pójdzie za Mną stokroć tyle otrzyma" i Żywot Wieczny odziedziczy.

Pierwszą zapłatę już otrzymałem tu na ziemi, bardzo proszę o modlitwę za mnie abym stał się godnym obietnic Chrystusowych ${ }^{52}$.

Był skromnej postury a jego organizm podatny był na choroby. W zimie 1985 roku przeszedł grypę wraz z innymi współbraćmi: ks. Stanisławem Urbańczykiem, ks. Józefem Turczynem. W roku następnym w czasie epidemii grypy choroba trzymała go przez miesiąc: od 19 I do 15 II 1986 roku. Dopiero po całkowitym wyzdrowieniu powrócił do pracy na portierni ${ }^{53}$.

Wśród potomnych pozostawił po sobie opinię wzorowego, skromnego i przykładnego salezjanina, szczerze pobożnego i na co dzień skromnego, otwartego na młodzież, z którą z łatwością nawiązywał kontakt, pełnego pogody ducha i poczucia humoru. Jeden ze współbraci napisał o nim:

${ }^{51}$ ASIK, b. sygn., Zespół: zmarli współbracia. Teczka personalna koad. Żukowskiego Stanisława, Dopuszczenie do ślubów wieczystych sporządzona przez ks. Michała Szafarskiego dnia 3 VI 1967 r. w Marszałkach.

${ }^{52}$ List koad. St. Żukowskiego z 19 XI 1993 r. (Oświęcim) do ks. Jacka Ryłko, rektora Wyższego Seminarium Duchownego Towarzystwa Salezjańskiego w Krakowie (zbiory adresata).

${ }^{53}$ AZSO, b. sygn., Kronika zakładu 1 I 1978 - 2 II 1996, zapis z 20 I 1985, 15 I, 15 II 1986. 
Człowiek głębokiej modlitwy i duchowości, bardzo pracowity, obowiązkowy i oddany Zgromadzeniu. Skromny i ascetyczny. Ukochał Zgromadzenie, młodzież i przełożonych. Nigdy nie słyszałem, aby kiedykolwiek źle o innych się wyrażał. Podstawa jego życia to modlitwa, praca, poświęcenie i ubóstwo. Miał bardzo znaczący wpływ na mój wybór życia i powołania salezjańskiego. Jestem przekonany o jego świętości już za życia. Wszyscy pamiętamy jak przez długie lata mieszkał przy portierni Zakładu Salezjańskiego w Oświęcimiu w pomieszczeniu, które nazywane było „tramwajem ${ }^{54}$.

Inny współnowicjusz ks. Henryk Skórski tak ocenia po pięćdziesięciu latach Stanisława: ${ }^{55}$

\begin{abstract}
Nas młodych zaskakiwał uśmiechem na co dzień, pracowitością przy zajęciach [codzienne porządki domowe - W. Ż.], pilnością w nauce nowicjackiej, lecz najbardziej zdrową i ufną pobożnością. W rozmowach koleżeńskich wyróżniał się nie tylko doświadczeniem życiowym, ale zawsze zdrowym rozsądkiem. Cieszył się dużą sympatią ze strony księdza magistra, przełożonych i nas współnowicjuszy. Cichy, pracowity, pobożny i rzeczowy, radosny i dojrzały. Pod koniec nowicjatu próbowaliśmy go pytać o jego dom rodzinny, ziemię albo o kontakty z ojcami franciszkanami. Odpowiadał krótko z uśmiechem, ale wyczuwaliśmy, że w salezjańskim domu na pewno ma swoje trwałe miejsce, co potwierdziło jego późniejsze, pracowite życie. Już po nowicjacie, w czasie naszych studiów, a zwłaszcza po naszych święceniach zawsze nam mówił: proszę księdza. Ta postać, ten współbrat-nowicjusz był dla nas dużo młodszych cichą i pewną podporą aby trwać i rozwijać się w powołaniu salezjańskim”.
\end{abstract}

$* * * * *$

W czasie exodusu na wschód we wrześniu 1939 roku, w ucieczce przed Niemcami, w drodze wpadł w ręce hitlerowców, a sądząc, że go rozstrzelają, ślubował Stanisław Panu Bogu, że jeżeli przeżyje szczęśliwie tę wojnę, to wstąpi do surowszego klasztoru niż franciszkanie, gdzie mu było dobrze. Wiek przeszkodził mu zrealizować tę obietnicę po wojnie. Na jego prośby odpowiedzieli przełożeni wielu zakonów negatywnie. Zdecydowali się przyjąć 45 letniego kandydata do zgromadzenia salezjanie prowincji krakowskiej.

W prośbie do przełożonego domu zakonnego w Marszałkach o dopuszczenie do złożenia ślubów wieczystych - ks. Michała Szafarskiego napisał: „Celem mego życia będzie stałe dążenie do doskonałości. Wierzę, że Niepokalana Wspomożycielka Wiernych, która nie patrząc na moje liczne grzechy wprowadziła mnie do Zgromadzenia Księży Salezjanów, pomagała w trudnościach, będzie i w dalszym ciągu mego życia Przewodniczką i Opiekunką aż doprowadzi do profesji wieczystej świętego w Niebie" ${ }^{56}$. I chociaż Rada Domu zakonnego w Marszałkach (ks. Michał Szafarski-dyrektor, ks. Edward Staszewski, ks. Franciszek Kielar) wydała

${ }^{54}$ Opinia o koad. Stanisławie Żukowskim współnowicjusza ks. Stanisława Kulpaczyńskiego z Lublina z 2 VIII 2010 r. (zb. aut.).

${ }^{55}$ Relacja ks. Hernyka Skórskiego z 29 IX 2011 r. - Wisła (zb. aut.).

${ }^{56}$ ASIK, b. sygn., Zespół: zmarli współbracia. Teczka personalna koad. Żukowskiego Stanisława, Podanie koad. St. Żukowskiego o dopuszczenie do złożenia ślubów wieczystych z 21 V 1967 r. - Marszałki. 
o koad. Stanisławie Żukowskim opinię: ,,[...] w wypełnianiu obowiązków powolny; mało zaradny - bez własnej inicjatywy", to jednak wszyscy członkowie Rady byli zgodni, że kandydat jest w pobożności gorliwy i posłuszny, w życiu wspólnotowym zgodny.

Najsmutniej ze swego życia wspominał Stanisław czasy II wojny światowej. Gdy groziło niebezpieczeństwo, a szczególnie gdy perspektywa wolności była żadna, w skrytości duszy myślał i nawet powiedział: czy nie lepiej było zginąć? Po latach, u schyłku swego życia, robiąc niejako obrachunek z przeszłością, na pół roku przed śmiercią napisał do przełożonego prowincji w Krakowie, że zginąć to rzecz najprostsza: „Ale trzeba było powrócić do rodziny, stanąć do pracy na roli, aby oddać kontyngent zbóż, mięsa, masła, mąki, sumy podatków. Przyszły również czasy wywózki na Sybir, rozkułaczania, kolektywizacji, i przy tym wszystkim trzeba było pamiętać, że jest się zakonnikiem, Polakiem, więc trzeba było płynąc pod prąd, nie iść do kołchozu, do współpracy z komunistami, trzeba było prowadzić gospodarstwo, opiekować się ciężko chora matką i uczyć dzieci katechizmu z okolicznych wiosek. Dziś gdy wspomnę te czasy to mówię, że warto było żyć a nie zginąć. Na imieniny śpiewają ,sto lat, sto lat”, no to już niedużo, mam 96 lat, to zostało cztery, w ciągu których trzeba będzie odejść" "57.

We wrześniu 2008 roku dziękując przełożonemu Prowincji św. Jacka w Krakowie - ks. Markowi Chrzanowi za przesłane życzenia imieninowe koad. Stanisław napisał: „Przy wieczornych pacierzach dziękuję Panu Bogu, że pozwolił jeszcze jeden dzień przeżyć". Siedem miesięcy później zmarł w Oświęcimiu, zajmując miejsce $\mathrm{w}$ ogrodzie salezjańskim w niebie zapewnionym przez świętego zakonodawcę salezjanów ks. Jana Bosko.

${ }^{57}$ ASIK, b. sygn., Zespół: zmarli współbracia. Teczka personalna koad. Żukowskiego Stanisława, Koad. Żukowski do inspektora ks. M. Chrzana z 24 IX 2008 r.-Oświęcim. 


\title{
A SALESIAN FATHER „ON A TRAM““. THE COADJUTOR ŻUKOWSKI
}

\section{3-2009}

\begin{abstract}
Summary
A Salesian Frather -the coadjutor Żukowski was born in 1913 in the Vilnius Region. After the border changes in our country in 1945, he lived in the Lithuanian Soviet Socialist Republic. He was brought up in a numerous religious family of farmers. From childhood he worked hard on the farm. As a parishioner of the parish Kalwaria near Vilnius he learnt Marian piety there. He was involved in the Catholic Youth Association, where he contributed to the development of education and religious life. He joined the Franciscans in Niepokalanów in 1938 but the outbreak of the Second World War prevented him from becoming a Franciscan monk. In Niepokalanów he met Maksymilian Maria Kolbe, who is already the saint. Stanisław stayed at home during the war and the post-war years of communist rule. Although he did not have any qualifications, he taught religion to the children in the period of communism. He was still, however, thinking of becoming a monk. Unfortunately, he was rejected by some orders in Poland because of his advanced age. When he was accepted by Salesians in Cracow, he felt really happy. After the death of his mother in January 1958 (he looked after her during the last 3 years of her life), he came to the People's Republic of Poland as a repatriant to join the Salesian Society. He was a man of prayer, hard-working, conscientious and devoted to the congregation. He was always modest and did not like to be in the centre of attention. While being in a monastery, he mainly served as a sacristan and a doorkeeper. The most important things in his life were: prayer, work, devotion and poverty. Plenty of his confreres regarded him as a saint even when he was still alive. He died in 2009 in Oświęcim and was buried in the Salesian tomb in this town.
\end{abstract}

